\title{
The Economics of Business Cycles Numerical Model Role of Fixed Costs
}

\section{Gerald Aranoff}

Ariel University, Ariel, Israel

Email: garanoff@netvision.net.il

How to cite this paper: Aranoff, G. (2020). The Economics of Business Cycles Numerical Model Role of Fixed Costs. Modern Economy, 11, 600-608.

https://doi.org/10.4236/me.2020.112044

Received: January 16, 2020

Accepted: February 24, 2020

Published: February 27, 2020

Copyright $\odot 2020$ by author(s) and Scientific Research Publishing Inc. This work is licensed under the Creative Commons Attribution International License (CC BY 4.0).

http://creativecommons.org/licenses/by/4.0/

(c) (i) Open Access

\begin{abstract}
This paper presents a simple numerical model of the economics of business cycles with illustrated demand and cost curves. This is a purely theoretical model inspired by the writings of John M. Clark (1884-1963). The model shows industry long-run equilibrium $(E(\pi)=0)$ under perfect competition for manufacturers to supply hypothetical fluctuating demand schedules, offpeak and peak, for a single non-durable product such as cement. The model has two plant types: old high fixed-cost Plant ${ }_{L}$ and modern low fixed-cost Plant $_{K^{*}}$. The model assumes linear total cost curves with absolute capacity limits for the two plant types. Both plant types have the same SACmin. Under perfect competition neither plant type will dominate. The plant assets are assumed durable, to last for 50 years, and specific to manufacturing only one product, $Q$. The model, with its rigid assumptions, shows that industry composed of only modern low fixed-cost Plants $s_{K}$ will increase the amplitude of the business cycle, the range of industry outputs between peak and off-peak, versus an industry composed of only old high fixed-cost Plants $s_{L}$. The implication is that under conditions of perfect competition and the model, reduction of fixed costs even while not reducing the SACmin-will lead to wider amplitude business cycles. The model shows a positive aspect of fixed costs: that one can expect that industry with high fixed costs to have reduced amplitude of the business cycle. Fixed costs in the model narrow the output levels between the trough and the peak of the business cycle. Some may find this a surprising result.
\end{abstract}

\section{Keywords}

Business Cycle, Numerical Model, Manufacturing, Marginal-Cost Pricing, Idle Capacity 


\section{Introduction}

\subsection{John M. Clark on Fixed Costs and the Business Cycle}

John M. Clark ranks among the most outstanding economists of the 20th century. Wikipedia: "John Maurice Clark (1884-1963) was an American economist whose work combined the rigor of traditional economic analysis with an "institutionalist" attitude. Clark was a pioneer in developing the notion of workable competition and the theoretical basis of modern Keynesian economics, including the concept of the economic multiplier". Clark sought strategic factors in business cycles, meaning factors of controlling importance ${ }^{1}$.

John M. Clark wrote passionately on fixed costs and the business cycle ${ }^{2}$ : "It is needless to point out that overhead costs play a fundamental part in the behavior of business at every stage of that many-sided phenomenon, the business cycle. The part they play is most paradoxical. For they make regular operation peculiarly desirable and peculiarly profitable, so that business feels a definite loss whenever output falls below normal capacity, and yet it is largely due to this very fact of large fixed capital that business breeds these calamities for itself, out of the laws of its own being. And the largest businesses, which have the highest percentage of constant costs due to invested capital, are, as we have seen, precisely the ones which fluctuate the most, so far as employment is an index. There is something about the commercial-industrial system which bewitches business so that it does just the thing it is trying to avoid, and is held back from doing just the thing it yearns to do-maintain steady operation and avoid idle overhead. And while the contributing causes of this strange auto-hypnosis are many and of varied character, technical, financial, commercial, and psychological; the underlying fact of large capital plays a central part, and the inelasticity of costs, sunk costs, and the shifting and conversion of overhead costs are all facts of major importance".

\subsection{Business Cycle Phases: Expansion, Peak, Contraction, Trough}

John M. Clark and Wesley Clair Mitchell studied empirical and theoretical theses of business cycles. John M. Clark in his famous Strategic factors in Business Cycles reproduces Wesley Clair Mitchell's reference dates for the four phases of business cycles 1855-1929 (See Figure 1). Clark writes ${ }^{3}$ : "The dates, based upon a study of business annals and the best statistical indicators of business activity available, purport to show the month and year of successive revivals and recessions in general business activity". In modern language the four phases of the business cycle are expansion, peak, contraction, and trough. Mitchell comments on his table of standard reference dates for business cycles": "The statistical investigator had to develop a sharper concept of the cyclical component in the

${ }^{1}$ Clark, 1934: pp. 183-190.

${ }^{2}$ Clark, 1923: p. 386.

${ }^{3}$ Clark, 1934: p. 10.

${ }^{4}$ Mitchell, 1930: p. 93. 


\begin{tabular}{|c|c|c|c|}
\hline Expansion Revival & Expansion High & Contraction Recession & Contraction Low \\
\hline January 1855 & June 1857 & July 1857 & December 1858 \\
\hline January 1859 & October 1860 & November 1860 & June 1861 \\
\hline July 1861 & April 1865 & May 1865 & December 1867 \\
\hline January 1868 & June 1869 & July 1869 & December 1870 \\
\hline January 1871 & October 1873 & November 1873 & March 1879 \\
\hline April 1879 & March 1882 & April 1882 & May 1885 \\
\hline June 1885 & March 1887 & April 1887 & April 1888 \\
\hline May 1888 & July 1890 & August 1890 & May 1891 \\
\hline June 1891 & January 1893 & February 1893 & June 1894 \\
\hline July 1894 & December 1895 & January 1896 & June 1897 \\
\hline July 1897 & June 1899 & July 1899 & December 1900 \\
\hline January 1901 & September 1902 & October 1902 & August 1904 \\
\hline September 1904 & May 1907 & June 1907 & June 1908 \\
\hline July 1908 & January 1910 & February 1910 & January 1912 \\
\hline February 1912 & January 1913 & February 1913 & December 1914 \\
\hline January 1915 & August 1918 & September 1918 & April 1919 \\
\hline May 1919 & January 1920 & February 1920 & September 1921 \\
\hline October 1921 & May 1923 & June 1923 & July 1924 \\
\hline August 1924 & October 1926 & November 1926 & December 1927 \\
\hline January 1928 & June 1929 & & \\
\hline
\end{tabular}

Figure 1. Standard reference dates for business cycles, U.S. Dr. Mitchell's table for the four phases of business cycles 1855-1929.

changes in a given series; he had also to discover what sort of whole the cyclical fluctuations of different series make up. These are problems on which investigators are actively working, spurred on by critics who hold that "the so-called business cycle" is a myth."

\subsubsection{Expansion Phase of the Business Cycle}

This is the prosperous business cycle phase. There are widespread feelings of optimism among consumers and producers. The economy is growing. Firms are hiring workers. Firms are building new plants and equipment. Expansion is the seven fat years of Pharaoh's dream in the Bible "Immediately ahead are seven years of great abundance in all the land of Egypt" (Genesis 41:29).

\subsubsection{Peak Phase of the Business Cycle}

The expansion phase is ending. Checks are operating blocking further expansion. Plants are operating at high rates of capacity utilization.

\subsubsection{Contraction Phase of the Business Cycle}

This is the declining business cycle phase. There are widespread feelings of pessimism among consumers and producers. Economic growth, if at all, is weak. Firms are hiring less. Firms are building fewer new plants and equipment. Contraction is the seven lean years of Pharaoh's dream: "After them will come seven years of famine, and all the abundance in the land of Egypt will be forgotten. As the land is ravaged by famine" (Ibid. 30).

\subsubsection{Trough Phase of the Business Cycle}

The contraction phase is ending. Consumers and producers are looking forward 
to a coming expansion phase of the business cycle. Plants are operating at low rates of capacity utilization.

\subsection{John M. Clark's Description of a Business Cycle}

John M. Clark describes the central features of a business cycle ${ }^{5}$ :

"[Expansion phase] Imagine a man who owns a farm, a wood lot, a coal pit, and an iron mine, and runs a self-sufficing establishment, spinning, weaving, and making all necessary tools and utensils. He hires his laborers and sells them the goods they use and produces whatever shows a profit. He finds that his establishment has times of great activity [Peak phase] and other times when there is not work enough for all [Contraction phase], and when idle hands are coming to him for support, or otherwise making nuisances of themselves [Trough phase]. On examination it turns out that during the busy times he is making more looms, more threshing machines, more wagons, etc., so fast that if he kept on he would have more than he could possibly use. And he is also making more clothes, building larger dwelling-houses, and furnishing comforts and recreation because the additional money he pays out in wages is coming back to him in the form of increased demand for all these goods. And this cannot last any longer than the source from which it flows. A man in such a position would be perfectly clear that he could not always be doubling his supply of threshing machines in two years. And when he found how much trouble it made to let the workers who were dependent on this kind of work, work themselves out of a job in the active period, he would probably begin scheduling this work so that he would get it done at a fairly regular rate. This would cut down the feverish activity which used to affect his whole force, but they would just get just as much work done in the end. In fact, they would get more, because some of the workers in the most unsteady trades would prove to be unnecessary and would find their way into some steadier occupation. This is a tolerably true picture of some of the central features of the business cycle".

\subsection{John M. Clark's Numerical Example of a Car Plant}

John M. Clark in his famous Studies in the Economics of Overhead Costs gives a detailed numerical example of total costs of a hypothetical car plant at ranging \% capacity utilization and frequencies 120 2/9, 100 2/9, 80 2/9, 60 2/9 and 0 1/9. At optimal $100 \%$ capacity utilization over a year the plant will produce 100 cars. Clark shows us a flexible budget, a basic tool in modern management accounting, for his imaginary car plant (See Figure 2). Clark concludes ${ }^{6}$ : "The resulting average is $\$ 1300$ per car, as compared to $\$ 1287$ per car if production were steady at 80 per cent capacity, and $\$ 1134$ per car working at 100 per cent. The probable total economic cost per car, is, then $\$ 1300$, if production averages 80 per cent of capacity. If the concern can sell eighty cars a year at an average price of $\$ 1300$, 


$\begin{array}{llllll}\text { Division } & 120 \% 2 / 9 & 100 \% 2 / 9 & 80 \% 2 / 9 & 60 \% 2 / 9 & 0 \% 1 / 9 \\ \text { Office, Sales, etc. } \$ & 20,100 & 16,900 & 16,460 & 16,240 & 9,000 \\ \text { Repairs and maitenance } \$ & 5,000 & 3,200 & 3,180 & 2,960 & 1,400 \\ \text { Indirect costs } \$ & 21,000 & 17,900 & 16,900 & 16,100 & 1,900 \\ \text { Direct costs } \$ & 68,000 & 51,400 & 42,700 & 34,000 & 6,000 \\ \text { Overhead charges } \$ & 24,240 & 24,000 & 23,760 & 23,520 & 23,400 \\ \text { Total costs } \$ & 138,340 & 113,400 & 103,000 & 92,820 & 41,700\end{array}$

Figure 2. Clark's numerical flexible budget of a car plant.

the enterprise will justify itself. If output is lower, cost will be higher and visa versa".

\section{Numerical Example}

\subsection{High FC Plant ${ }_{L}$ and Low FC Plant ${ }_{K}$}

In my numerical example I assume fluctuating demand schedules, off peak and peak. The product $Q$ is highly standardized and perishable such as cement that is difficult to store for long periods. Demand fluctuates between $P_{1}$ with frequency $w_{1}$ and $P_{2}$ with frequency $w_{2}$. For simplicity, I assume:

$$
\begin{gathered}
P_{1}=1.152 / Q_{1} w_{1} \\
P_{2}=3.456 / Q_{2} w_{2} \\
w_{1}=w_{2}=0.5 .
\end{gathered}
$$

\subsection{The Industry of Manufacturing Product $Q$}

Investors seeking to invest in manufacturing and production of product $Q$ can choose between two hypothetical plants, modern low FC Plant ${ }_{K}$ and old high FC Plant $_{L}$. Both plants have durable and specific assets and linear short-run total costs curves with absolute capacity limits. The plants differ in per-unit variable cost, $(b)$, per-unit fixed cost, $(\beta)$, and capacity per plant, $(q)$. My notation is that $b$ is the constant per-unit variable operating cost. $\beta$ is the per-unit fixed capacity cost where the numerator is the constant fixed costs per week and the denominator is the maximum the plant can produce in a week. I assume periods of a week. I assume $\mathrm{q}$ is the operating rate in a week. Let $n$ be the number of plants, a continuous variable. Fractional plants are permitted. No long-run economies of scale are assumed for each plant.

In my model, investors can order any number of plants ${ }_{K}$ or plants ${ }_{L}$. Plant ${ }_{K}$ relies more on outsourcing raw materials and parts and using just-in-time lean accounting systems, which lowers fixed costs and raises its $b$. Investors cannot choose a mixture of plant $_{K}$ and plant ${ }_{L}$. The industry will be comprised of only plants $_{K}$ or only plants .

$$
\begin{gathered}
\text { Expected total revenues }=E(T R)=P_{1} Q_{1} w_{1}+P_{2} Q_{2} w_{2} . \\
\text { Expected total costs }=E(T C)=b\left(Q_{1} w_{1}+Q_{2} w_{2}\right)+\beta Q_{2} \\
\text { Expected profits }=E(\pi)=E(T R)-E(T C) .
\end{gathered}
$$


Long-run equilibrium requires $E(\pi)=0$.

For simplification in my numerical example, let:

$$
\begin{gathered}
b_{L}=\$ 24 \text { per ton } \\
\beta_{L}=\$ 12 \text { per ton } \\
q_{L}=0.72 \text { ton per week } \\
b_{K}=\$ 31.2 \text { per ton } \\
\beta_{K}=\$ 4.8 \text { per ton } \\
q_{K}=0.9 \text { ton per week }
\end{gathered}
$$

Plant $_{K}$ illustrates modern low FC operations. Plant ${ }_{L}$ illustrates old high FC operations. Under perfect competition plants shut down temporarily when market prices fall below short-run variable costs and produce at capacity when market prices are above variable costs. For simplicity, I assume that when market prices are equal to variable costs, plants will produce to satisfy the market but not more and not less. Figure 3 shows the data for the industry of manufacturing product $\mathrm{Q}$ under fluctuating demand with only Plants $\mathrm{L}_{L}$.

Figure 4 graphs industry with only plants ${ }_{L}$ manufacturing product $Q$. The industry capacity is 72.0 tons per week from 100 plants $_{L}$. Long run equilibrium exists because industry demand for product $\mathrm{Q}$ is satisfied and expected profits over the cycle are zero. The $E\left(A C_{L}\right)=\$ 38.4$. This corresponds to John M. Clark's probable economic cost of a car of his detailed numerical example of car plant page 185 in his Studies in the Economics of Overhead Costs. Comparing

$$
\begin{array}{lr}
\text { Let } \mathrm{P}_{1}=1152 / Q_{1} w_{1} & \\
\text { Let } w_{1}= & 0.5 \\
\text { Let } \mathrm{P}_{2}=3456 / Q_{2} w_{2} & \\
\text { Let } w_{2}= & 0.5 \\
S T C_{L}=b_{L} q_{i}+\beta_{L} q_{L} & \\
\text { Let } b_{L}= & \$ 24 \text { per ton } \\
\text { Let } \beta_{L}= & \$ 12 \text { per ton } \\
\text { Let } q_{L}= & 0.72 \text { tons per week } \\
F C_{L}=\beta_{L} \times q_{L}= & \$ 8.64 \text { per week } \\
S A C m i n_{L}= & \$ 36 \text { per ton } \\
P_{1}=b_{L}= & \$ 24 \text { per ton } \\
Q_{1}= & \$ 4.0 \text { tons per week } \\
P_{2}=b_{L}+\beta_{L} / w_{2}= & \$ 48.00 \text { per ton } \\
Q_{2}= & 72.0 \text { tons per week } \\
n_{L}=Q_{2} / q_{L} & 100.0 \text { plants } \\
E(T R)_{L}=P_{1} Q_{1} w_{1}+P_{2} Q_{2} w_{2}= & \$ 2304 \\
E(T C)_{L}=b_{L}\left(Q_{1} w_{1}+Q_{2} w_{2}\right)+\beta_{L}\left(Q_{2}\right)= & \$ 2304 \\
E(\pi)_{L}= & \$ 0 \\
Q_{2}-Q_{1}= & 24.0 \text { tons per week } \\
E(Q)=Q_{1} w_{1}+Q_{2} w_{2}= & 60.0 \text { tons per week } \\
E\left(A C_{L}\right)=E\left(T C_{L}\right) / E(Q)= & \$ 38.4 \\
E\left(A C_{L}\right)-S A C m i n_{L}= & \$ 2.4 \\
&
\end{array}
$$

Figure 3. LR equil. high FC Plant and $_{1} W_{1} D_{2} w_{2}$. 
$E\left(A C_{L}\right)=\$ 38.4$ with the SACmin of $\$ 36$ shows a waste of partial utilization (Clark's term) of $\$ 2.4$.

Figure 5 shows the data for the industry of manufacturing product Q under fluctuating demand with only Plants ${ }_{K}$. Figure 6 graphs industry with only Plants $_{K}$ manufacturing product Q. The industry capacity is 84.7 tons per week from 94.1 Plants ${ }_{K}$. Long run equilibrium exists because industry demand for product $\mathrm{Q}$ is satisfied and expected profits over the cycle are zero. The $E\left(A C_{K}\right)=\$ 37.9$. Comparing $E\left(A C_{K}\right)=\$ 37.9$ with the SACmin of $\$ 36$ shows a waste of partial utilization of \$1.9. It is to be expected less waste of partial utilization with a lower FC operation. This is an important point.

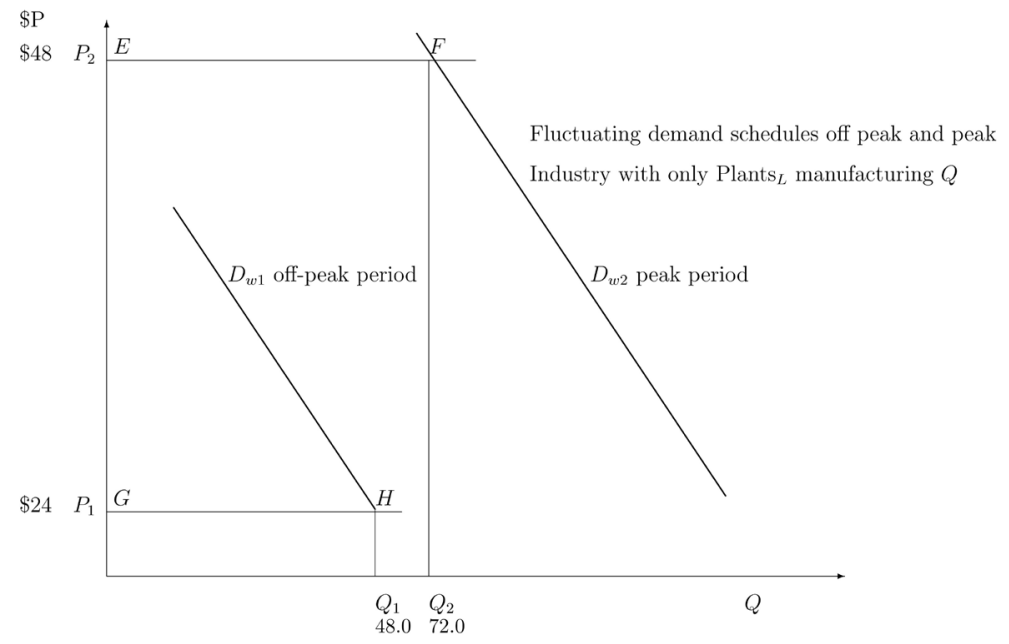

Figure 4. Graph LR equil. high FC Plant ${ }_{L}$ and $D_{1} w_{1} D_{2} w_{2}$.

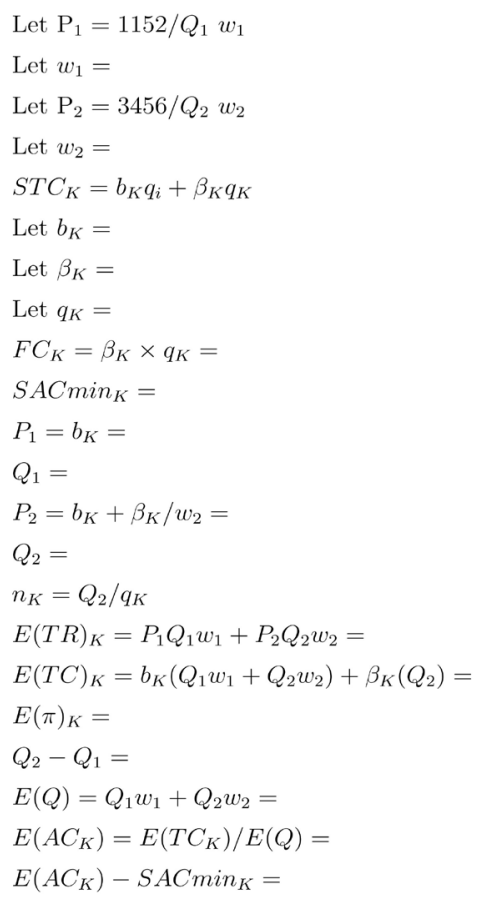

Figure 5. LR equil. low FC Plant $K$ and $D_{1} w_{1} D_{2} w_{2}$. 


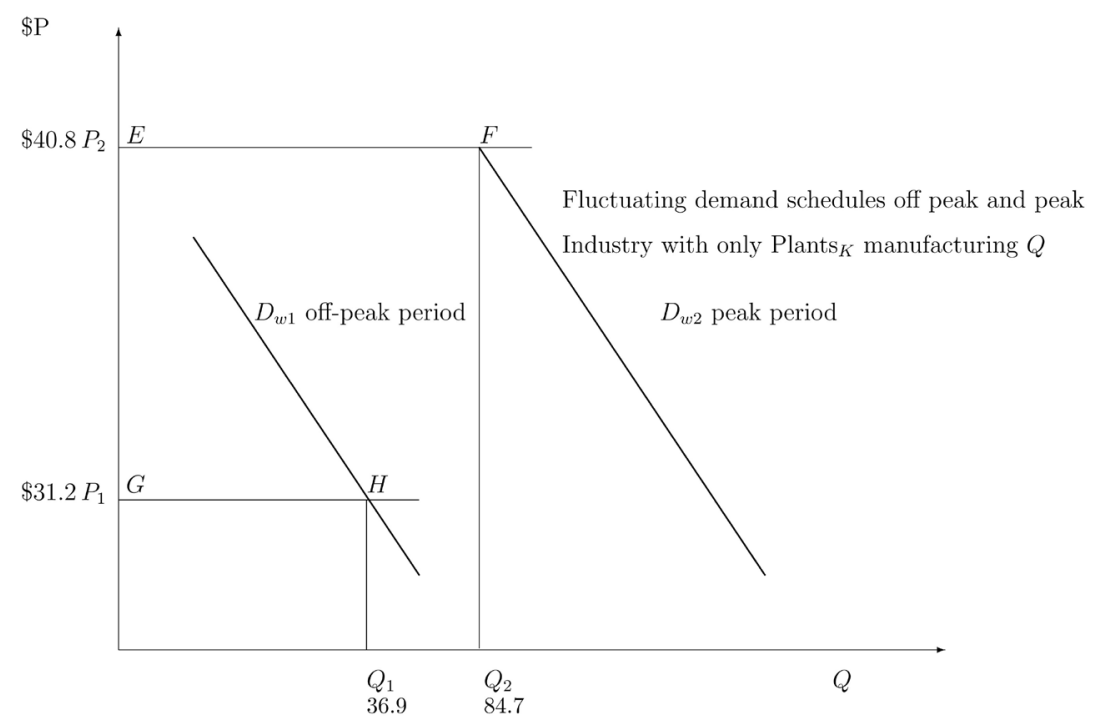

Figure 6. Graph LR equil. low FC Plant $K_{K}$ and $D_{1} w_{1} D_{2} w_{2}$.

\section{Conclusion and Policy Implication}

This paper is a theoretical analysis comparing, under conditions of perfect competition, high FC plants $_{L}$ versus low FC plants ${ }_{K}$ making a perishable standardized product facing demand fluctuations. The plants have linear total costs and capacity limits with no economies of scale. The plants have durable and specific assets and the same SACmin. The model shows a positive aspect of fixed costs: that one can expect that industry with high fixed costs to have reduced amplitude of the business cycle. Fixed costs in the model narrow the output levels between the trough and the peak of the business cycle. Some may find this a surprising result.

John M. Clark was critical of perfect competition, e.g.7: "It is decidedly doubtful whether it would be economically feasible to make profits enough in such periods [of peak demand] to offset the losses incurred in normal and subnormal periods. And if it were economically feasible, there might be other serious obstacles and drawbacks in the way of exploiting the profitable periods by raising prices as graspingly as would be necessary to balance the accounts. It would be very bad public relations, in a period when industry needs good public relations very much".

Surely, if Clark were alive today, he would welcome modern plants $_{K}$ that have lower FC than older plants ${ }_{L}$ because the required price to balance the accounts under perfect competition would be lower. Note that $P_{2}=\$ 40.8$ in Figure 6 is and in Figure 3 is $\$ 48.0$. Clark would especially welcome that waste of partial utilization would be lower with plants ${ }_{K} \$ 1.9$ in Figure 6 versus $\$ 2.4$ in Figure 4.

\section{Conflicts of Interest}

The authors declare no conflicts of interest regarding the publication of this paper.

${ }^{7}$ Clark, 1961: p. 122. 


\section{References}

Clark, J. M. (1923). Studies in the Economics of Overhead Cost. Chicago: The University of Chicago Press.

Clark, J. M. (1934). Strategic Factors in Business Cycles. New York: The National Bureau of Economic Research.

Clark, J. M. (1961). Competition as a Dynamic Process. USA: The Brookings Institution.

Mitchell, W. C. (1930). Business Cycles. In Encyclopedia of the Social Sciences. New York: The Macmillian Company. 